\title{
PENGARUH KEMANDIRIAN BELAJAR TERHADAP KEMAMPUAN PEMECAHAN MASALAH MATEMATIS SISWA SMP KOTA BANDUNG
}

\author{
Mayasari $^{1}$, Tina Rosyana ${ }^{2}$ \\ 1,2 Pendidikan Matematika, IKIP SILIWANGI, Jl. Terusan Jendral Sudirman Cimahi 40526 \\ Mayasari15510238@gmail.com
}

\begin{abstract}
This study aims to determine the effect of learning independence on junior high school mathematical problem solving abilities. The method used in the study is correlational based on a quantitative approach that aims to determine whether there is a relationship between learning independence towards mathematical problem solving abilities and if there is how much the relationship between the two. The population in this study is in one of the state junior high schools in the city of Bandung with the samples taken are all class VII-B Instruments used in the study consisted of 5 items test questions mathematical problem-solving ability and learning independence questionnaire consisting of 28 statements. Based on the results obtained that there is a positive relationship between the independence of learning high school students with mathematical problem solving abilities of $17 \%$ influenced by learning independence and $83 \%$ influenced by other factors.
\end{abstract}

Keywords : Learning Independence, Mathematical Problem Solving Abilities

\begin{abstract}
Abstrak
Penelitian ini bertujuan untuk mengetahui pengaruh kemandirian belajar terhadap kemampuan pemecahan masalah matematis tingkat SMP. Metode yang digunakan dalam penelitian adalah korelasional berdasarkan pendekatan kuantitatif yang bertujuan untuk mengetahui apakah ada hubungan antara kemandirian belajar terhadap kemampuan pemecahan masalah matematis dan jika ada seberapa besar humbungan antar keduanya. Populasi dalam penelitian ini yaitu di salah satu SMP Negeri di Kota Bandung dengan sampel yang diambil adalah seluruh kelas VII-B Instrumen yang digunakan dalam penelitian terdiri dari 5 butir soal tes kemampuan pemecahan masalah matematis serta angket kemandirian belajar yang terdiri dari 28 pernyataan. Berdasakan hasil yang diperoleh bahwa terdapat hubungan yang positif antara kemandirian belajar siswa SMA dengan kemampuan pemecahan masalah matematis sebesar $17 \%$ dipengaruhi oleh kemandirian belajar dan $83 \%$ dipengaruhi oleh faktor lainnya.
\end{abstract}

Kata kunci : kemandirian belajar, kemampuan pemecahan masalah matematis

Persaingan yang begitu menyeluruh di setiap Negara memeksakan warga harus turut serta dalam memajukan Negara sendiri agar menjadi negara yang dicampakan oleh Negara lain. Berbagai upaya dilakukan untuk menjadikan sumber daya manusia yang mampu bersaing secara global. Tombak yang menjadikan sumber daya tersebut salah satunya adalah dengan berpendidikan. Dalam berpendidikan adanya suatu proses pembelajaran yang terjadi. Hal tersebut didukung oleh pernyataan (Afrilianto 2012) yang mengungkapkan bahwa proses pembelajaran adalah adanya interaksi antar individu dengan individu, individu dengan kelompok ataupun kelompok dengan kelompok lainnya yang mengandung nilai pendidikan serta diharapkan adanya suatu peruaban tingkan laku agar menjadi lebih baik. Interaksi yang terjadi haruslah menghasilkan suatu ilmu baru yang dapat dimanfaatkan dalam kehidupan bermasyarakat. 
Dalam dunia pendidikan dituntut untuk mempelajari berbagai macam bidang ilmu agar kemampuan yang dimiliki bertambah dan mampu untuk dikembangkan salah satunya bidang ilmu matematika. Menurut (Zulfah 2018) Pada dunia pendidikan khususnya di Indonesia, matematika merupakan salah satu mata pelajaran wajib yang dipelajari mulai jenjang sekolah dasar hingga sekolah menengah. Pendapat lain menurut (Rosyana 2015) mempelajari ilmu matematika sangat penting karena ilmu matematika sangat erat kaitannya dalam kehidupan sehari-hari. Sejalan dengan (Ulya 2015) yang menyatakan bahwa belajar matematika adalah proses yang rutin dilakukan dalam kehidupan bermasyarakat seperti proses jual beli atau transaksi lainnya. Pendapat lain menutut (Yuliani, Zulfah dan Zulhendri 2018) matematika adalah ilmu dasar segala bidang ilmu yang mendasari perkembangan teknologi modern, mempunyai peran penting dalam berbagai disiplin ilmu dan memajukan daya pikir manusia

Ilmu matematika selalu digunakan pada aktivitas kehidupan sehari-hari maka dari itu matematika sangat penting untuk dipelajari oleh setiap peserta didik. Matematika merupakan mata pelajaran yang memerlukan penguasaan konsep awal yang harus diketahui oleh siswa agar mampu mengaitkan pada konsep baru. Menyampaikan konsep matematis haruslah dilakukan dengan strategi yang tepat agar pembelajaran tidak menjadi pasif dengan demikian tujuan dari pembelajaran dapat dicapai. Kurangnya strategi atau metode pembelajaran yang diterapkan dalam proses belajar mengajar mengakibatkan sulitnya siswa untuk mengembangkan kemampuan pemecahan masalah yang dihadapinya. Hal tersebut sejalan dengan ungkapan (Harahap 2015) yang mengungkapkan bahwa masih banyak guru di Indonesia yang menggunakan metode pembelajaran yang masih sederhana seperti ceramah. Selain itu (Suherman 2008) menyatakan bahwa kemampuan pemecahan masalah matematis itu adalah kegiatan yang yang dilakukan dengan cara mengamati,menelaah,mencoba dan membuat hipotesis untuk menyelesaikan suatu masalah matematis yang dihadapi. Dari salah satu indikator kemampuan pemecahan masalah menurut Lowry (Sumarmo 2015 ) menyatakan bahwa siswa mampu mengidentifikasi unsur yang diketahui dalam masalah, unsur yang ditanyakan, serta kecukupan unsur-unsur yang diperlukan. Pada tahap indikator tersebut perlu adanya suatu kemandirian belajar agar dalam proses pembelajaran siswa mampu memenuhi salah satu indikator yang terdapat pada kemampuan pemecahan masalah matematis.

Fakta dilapangan masih sangat rendah kemampuan pemecahan masalah matematis siswa dilihat dari kemandirian belajarnya. Rendahnya kemampuan pemecahan masalah memiliki beberapa gejala tetrentu. Menurut (Zulfah 2018) gejala-gejala yang berkaitan dengan rendahnya kemampuan pemecahan masalah matematis diantaranya: 1) Sebagian besar siswa tidak bisa mengerjakan soal yang berbeda dari contoh soal yang diberikan guru. 2) Sebagian besar siswa tidak bisa memahami soal yang berbentuk soal cerita dengan baik. 3)Sebagian besar siswa tidak bisa menyelesaikan soal-soal aplikasi atau soal-soal pemecahan masalah. 4) Siswa menjawab soal tanpa menggunakan langkah-langkah umum pemecahan masalah. Rendahnya kemampuan pemecahan masalah perlu di tinjau pula dari kemandirian belajar yang dimiliki oleh siswa. Pendapat 
lain menurut (Andayani dan Lathifah 2019) Kurangnya kemampuan pemecahan masalah siswa yang menyebabkan siswa hanya bisa mengerjakan soal rutin atau soal yang sama persis dengan yang diberikan oleh guru, sehingga siswa tidak dibiasakan mengerjakan soal yang tidak rutin yang mengakibatkan siswa mengalami kesalahan-kesalahan dalam menyelesaikan soalmatematika

Kemandirian belajar menurut (Sugandi, 2013) adalah suatu sikap yang dimiliki siswa yang berkarakteristis berinisiatif dalam belajar, mendiagnosis kebutuhan belajar, menetapkan tujuan belajar, memonitor, mengatur dan mengontrol kinerja atau belajar, memandang kesulitan sebagai tantangan, mencari dan memanfaatkan sumber belajar yang relevan, memilih dan menetapkan strategi dalam belajar, mengevaluasi proses dan hasil belajar, serta self-concept (konsep diri). Kemandirian belajar bukan berarti belajar secara mandiri namun kemandirian belajar dapat diartikan bahwa siswa belajar tanpa bergantung pada pemberian dari guru namun siswa mencoba menyelesaikan pesoalan tanpa menunggu jawaban dari guru. Hasil dari penelitian (Ayundaninghrum 2017) yang berjudul "pengaruh kedisiplinan dan kemandiriann belajar terhadap kemampuan pemecahan masalah matematika" bahwa terdapat pengaruh yang signifikan antara kedisiplinan dan kemandirian belajar terhadap kemampuan pemecahan masalah matematis namun diperlukan adanya penelitian lebih lanjut. Dari hasil penelitian yang dilakukan sebelumnya maka penulis hendak meneliti lebih lanjut pengaruh kemandirian belajar terhadap kemampuan pemecahan masalah matematis di salah satu SMA Swasta di Kota Cimahi.

\section{METODE PENELITIAN}

Metode penelitian yang dilakukan oleh peneliti yaitu metode korelasional dengan pendekatan yang digunakan adalah kuantitatif. Menurut (Akhidayat 2018) adanya pengaruh yang berkesinambunga antara kemandirian belajar siswa terhadap kemampuan berpikir kreatif matematis dan metode penelitian korelasional dengan pendekatan kuantotatif dapat menjadi alternatif dalam metode penelitian yang digunakan.Adapun tujuan dari metode yang digunakan adalah untuk mengetahui seberapa besar pengaruh atau hubungan antara dua atau lebih dari setiap variabel yang diteliti. Populasi dalam penelitian dilakukan di salah satu SMP Negeri yang berada di Kota Bandung. Sampel yang digunakan dalam penelitian ini adalah seluruh siswa kelas IX-B. Instrumen dalam penelitian ini yaitu berupa 5 butir soal pemecahan masalah matematis serta angket kemandirian belajar sebanyak 28 pernyataan yang terdiri dari 14 penyataan positif dan 14 pernyataan negatif.

\section{HASIL DAN PEMBAHASAN}

Agar mendapatkan hasil seberapa besar pengaruh kemandirian belajar terhadap kemampuan pemecahan masalah mnatematis dalam metode penelitian ini yang pertama adalah data harus berdistribusi normal maka dari itu uji normalitas lah yang pertama dilakukan sebelum uji linearitas dan uji regresi data. Menurut (Fajriyah,Nugraha, Akbar, dan Bernard 2018) teknik pengambilan keputusan dalam metode korelasional sebelum dilakukan uji statistika regresi, sebagai prasyarat 
terlebih dahulu dilakukan uji normalitas data dan uji linearitas, jika data berdistribusi normal dan linear maka dilanjutkan dengan uji regresi linear. Berikut adalah hasil dari uji normalitas data yang dilakukan disajikan dalam Tabel 1.

\section{Tabel 1}

Uji Normalitas Data

\begin{tabular}{l|r|r|r|r|r|r}
\hline \multirow{2}{*}{} & \multicolumn{3}{|c|}{ Kolmogorov-Smirnow } & \multicolumn{3}{c}{ Shapiro-Wilk } \\
\cline { 2 - 7 } & Statistic & \multicolumn{1}{c|}{ df } & \multicolumn{1}{c}{ Siq. } & Statistic & \multicolumn{1}{c}{ df } & \multicolumn{1}{c}{ Siq. } \\
\hline Tes & .127 & 35 & .168 & .941 & 35 & .062 \\
Angket & .148 & 35 & .052 & .943 & 35 & .071 \\
\hline
\end{tabular}

Dari hasil uji normalitas data didapat nilai probabilitas sig. > 0,05. Maka dapat disimpulkan hasil dari uji normalitas yang dilakukan bahwa data berdistribusi normal. Setelah data dinyatakan berdistribusi normal maka tahap selanjutnya yang dilakukan adalah uji linearitas data yang bertujuan untuk mengetahui apakah ada perbedaan kelinearan antara kemandirian belajar terhadap kemampuaan pemecahan masalah matematis siswa. Berikut hasil uji linearitas data yang diperoleh disajikan dalam Tabel 2.

\section{Tabel 2}

Uji Linearitas Data

\begin{tabular}{|c|c|c|c|c|c|c|c|}
\hline & & & $\begin{array}{l}\text { Sum of } \\
\text { Squares }\end{array}$ & df & Mean Square & $\mathrm{F}$ & Sig. \\
\hline \multirow[t]{5}{*}{ Tes *Angket } & Between Groups & (Combined) & 108.721 & 14 & 7.766 & .986 & .499 \\
\hline & & Linearity & 4.465 & 1 & 4.465 & .567 & .460 \\
\hline & & Deviation from Linearity & 104.257 & 13 & 8.020 & 1.019 & .471 \\
\hline & Within Groups & & 157.450 & 20 & 7.872 & & \\
\hline & Total & & 266.171 & 34 & & & \\
\hline
\end{tabular}

Dasar dari pengambilan keputusan pengujian data adalah jika probabilitas sig. > 005 maka tidak terdapat perbedaan kelinearan antar variabel. Hasil dari uji lineartas data yang dilakukan didapat bahwa nilai probabilitas untuk nilai Deviation of Linearity sig. 0,996>0,05 berarti tidak terdapat perbedaan kelinearan antara kemandirian belajar terhadap kemampuan pemecahan masalah matematis siswa ini menunjukan bahwa kemampuan pemecahan masalah matematis dan kemandirian belajar linear. Berikutnya dilakukan uji regresi data yang bertujuan untuk mengetahui apakah terdapat pengaruh yang positif antara kemandirian belajar terhadap kemampuan pemecahan masalah matematis siswa serta seberapa besar pengaruh kemandirian belajar terhadap kemampuan pemecahan masalah siswa. Berikut hasil dari uji regresi data di sajikan dalam Tabel 3, Tabel 4, dan Tabel 5. 


\section{Tabel 3}

Uji Regresi Data

\begin{tabular}{rr|r|r|r|r|r}
\hline & \multicolumn{1}{c|}{$\begin{array}{c}\text { Sum of } \\
\text { Model }\end{array}$} & \multicolumn{1}{c|}{ Squares } & \multicolumn{1}{c|}{ df } & Mean Square & \multicolumn{1}{c}{ F } & \multicolumn{1}{c}{ Sig. } \\
\hline 1 & Regression & 4.465 & 1 & 4.465 & .563 & $.458 \mathrm{a}$ \\
& Residual & 261.707 & 33 & 7.931 & & \\
& Total & 266.171 & 34 & & & \\
\hline
\end{tabular}

Dari hasil uji regresi yang didapat bahwa nilai positif probabilitas sig. 0,458 $>0,05$ hal tersebut menunjukan bahwa terdapat pengaruh positif dan saling bergantung antara kemandirian belajar dengan kemampuan pemecahan masalah matematis dengan taraf $5 \%$.

\section{Tabel 4}

Model summary

\begin{tabular}{|l|l|r|r|r|}
\hline $\begin{array}{l}\text { Mode } \\
\perp\end{array}$ & $\mathrm{R}$ & $\mathrm{R}$ Square & $\begin{array}{c}\text { Adjusted R } \\
\text { Square }\end{array}$ & $\begin{array}{c}\text { Std. Error of } \\
\text { the Estimate }\end{array}$ \\
\hline 1 & $.130^{\mathrm{a}}$ & .017 & -.013 & 2.816 \\
\hline
\end{tabular}

Dari hasil data yang didapat pada Tabel 4 bahwa nilai koefisien determinasi ( $R$ Square) yang menunjukan pengaruh kemandirian belajar terhadap kemampuan pemecahan masalah matematis siswa sebesar 0, 17 atau $17 \%$ hal tersebut berarti kemampuan pemecahan masalah matematis siswa dipengaruhi oleh kemandirian belajar sebesar $17 \%$ dan dipengaruhi oleh faktor lain sebesar $83 \%$.

\section{Tabel 5}

Persamaan Regresi

\begin{tabular}{|c|c|c|c|c|c|c|}
\hline \multirow{2}{*}{\multicolumn{2}{|c|}{ Madel }} & \multicolumn{2}{|c|}{ Unstandardized Coefficients } & \multirow{2}{*}{$\begin{array}{c}\begin{array}{c}\text { Standardized } \\
\text { Coefficients }\end{array} \\
\text { Beta } \\
\end{array}$} & \multirow[b]{2}{*}{$t$} & \multirow[b]{2}{*}{ Siq. } \\
\hline & & B & Std. Error & & & \\
\hline 1 & $\begin{array}{l}\text { (Constant) } \\
\text { Angket }\end{array}$ & $\begin{array}{r}67.727 \\
.078\end{array}$ & $\begin{array}{r}8.679 \\
.105\end{array}$ & 130 & $\begin{array}{r}7.804 \\
.750\end{array}$ & $\begin{array}{l}.000 \\
458\end{array}$ \\
\hline
\end{tabular}

Dilihat pada tabel persamaan regresi didapat persamaan antara kemandirian belajar dengan kemampuan pemecahan masalah matematis adalah:

$$
y=67,727+0,078 x
$$

Pada tabel denagn kolom B terlihat bahwa angket kemandirian belajar bernilai positif sebesar 0,078 dari hasil yang diperoleh tabel dan kemampuan pemecahan masalah matematis bernilai positif sebesar 67,727 maka dapat diartikan bahwa jika kemandirian belajar bertambah maka kemampuan pemecaahan masalah matematis akan bertambah pula begitu pula jika sebaliknya. 


\section{Pembahasan}

Berikut adalah soaal dan jawaban tes kemampuan pemecahan masalah matematis:

3. Harga tiket masuk ke ruang pameran karinding untuk anak adalah Rp 2000,00 sedangkan harga tiket masuk ruang pameran karinding dewasa adalah Rp 3000,00. Pada hari minggu terjual 540 tiket dengan hasil penjualan Rp 1.260.000,00. Tentukanlah banyak masing-masing tiket masuk anak dan dewasa yang terjual!

Gambar 1. Soal Tes Kemampuan Pemecahan Masalah Matematis

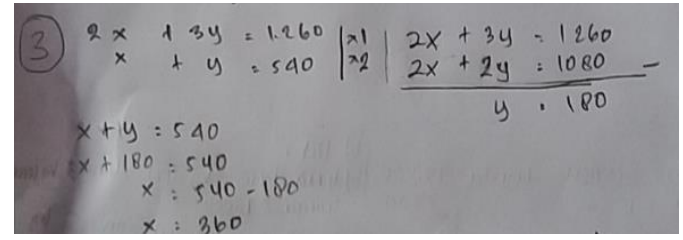

Gambar 2. Jawaban Siswa Dengan Kategori Kemandirian Siswa Kurang

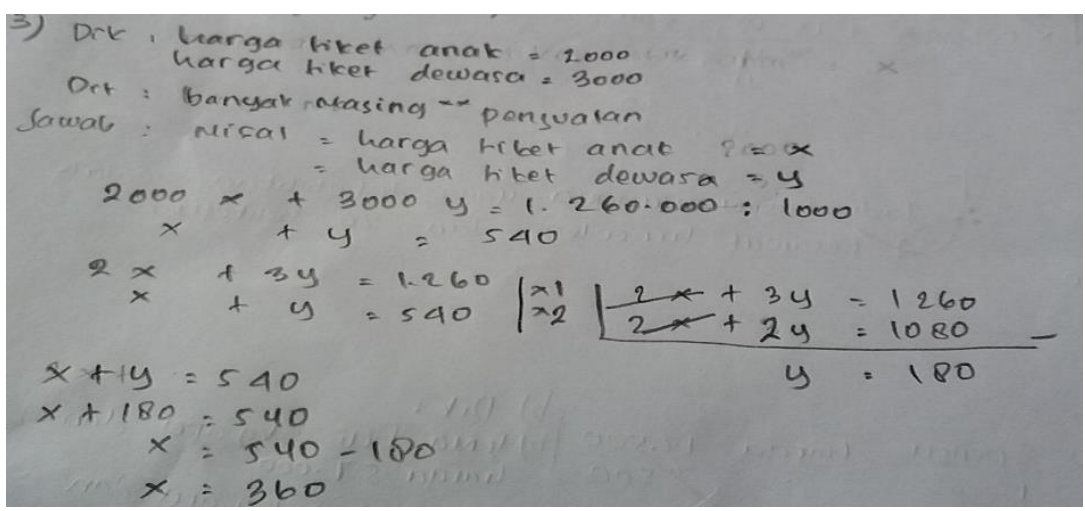

Gambar 3. Jawaban Siswa Dengan Kategori Kemandirian Belajar Sedang

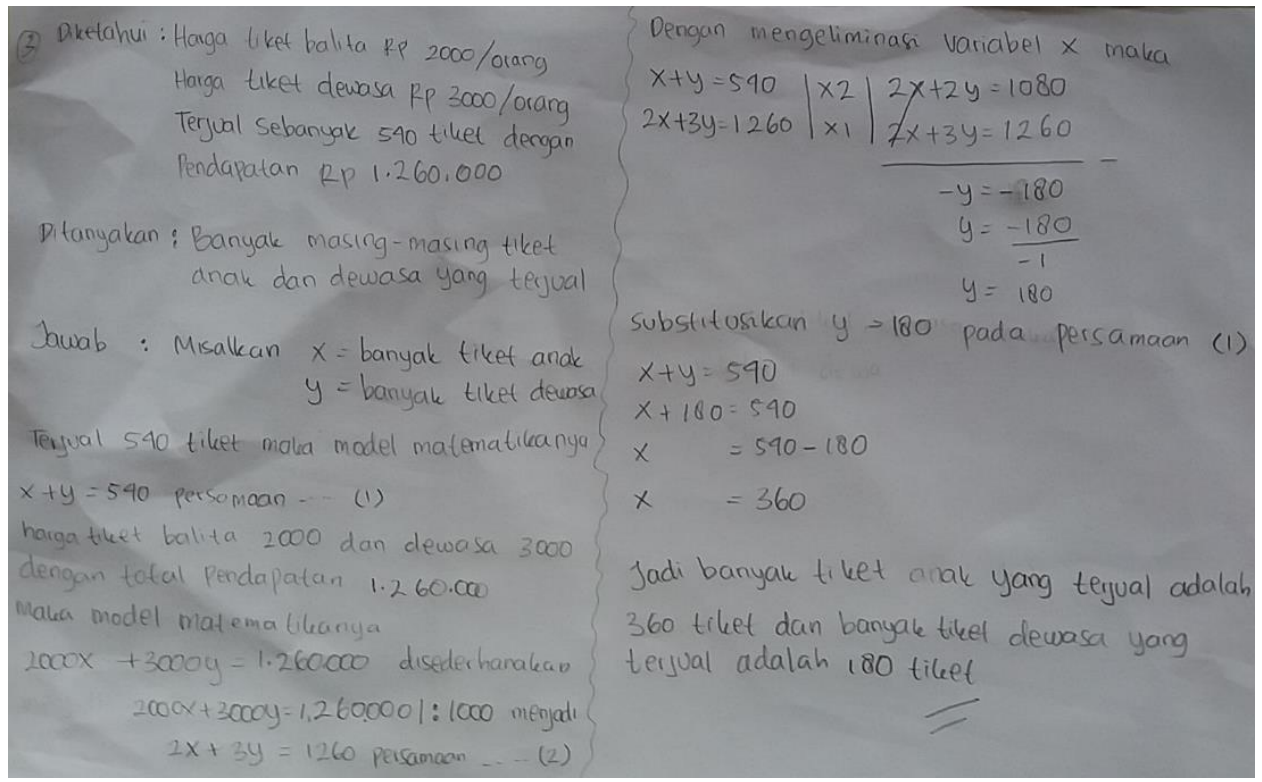

Gambar 4. Jawaban Siswa Dengan Kategori Kemandirian Belajar Tinggi 
Pada Gambar 1 siswa diminta untuk mencantumkan apa yang diketahui, ditanyakan, serta mencantumkan kesimpulan dari hasil yang diperoleh. Namun pada gambar dua siswa tidak mencantumkan apa yang diketaahui, ditanyakan serta tidak pula mencaantumkan keimpulan daari hasil yang diperoleh. Hal tersebut merupakan rendahnya kemandirian belajar atas indikator menjelaskan atau menginterpretasikan hasil sesuai permaslahan awal. Maka jawaban siswa tergolong dengan kemandirian belajar yang rendah. Sedangkan pada gambar 3 siswa sudah mencantumkan aapa yang diketahui dan ditanyakan dalam soal namun masil belum mencantumkan kesimpulan daari hasil yang ditemukan. Hal tersebut merupakan bahwa siswa telah mencantumkan unsur yang diketahui, ditanyakan setra kecukupan unsur yang ditanyakan namun inisiatif belajar masih belum cukup karena tidak menjelaskan atau menginterpretasikan hasil sesuai permasalahan awal. Lain halnya dengan gambar 4 siswa telah mencantumkan unsur yang diketahui, ditanyakan serta mencantumkan kesimpulan daari hasil pengerjaannya. Hal tersebut menunjukan bahwa kemandirian belajar memiliki pengaruh terhadap jawaban yang diberikan oleh siswa. Hal tersebut sejalan dengan (Sumarmo 2015:119) yang menyatakan bahwa semakin tinggi kemampuan pemecahaan masalah matematis siwa akan semakin tinggi pula kemandirian belajar yang dimilikinya. Menyimpulkan penjelasan diatas bahwasannya kemandirian harus dikembangkan terhadap siswa agar kemampuan pemecahan masalah matematis semakin meningkat dimiliki oleh siswa. Sejalan dengan itu Shunck dan Zimmerman (Sumarmo 2015: 115) memberikan saran bahwa kemandirian belajar akan efektif jika dikembangkan pada pelajar.

\section{SIMPULAN}

Dari hasil pembahasan yang telah dipaparkan maka kesimpulan yang diperoleh adalah terdapat hubungan yang linear antara kemandirian belajar denagn kemampuan pemecahan masalah matematis siswa. Kemampuan pemecahan massalah matematis siswa dipengaruhi oleh kemandirian belajar sebesar $21,3 \%$ dan dipengaruhi oleh faktor lainnya sebesar 78,7 \% terlihat dari perbedaan jawaban siswa yang memiliki kemandirian belajar rendah, sedang dan tinggi.

\section{DAFTAR PUSTAKA}

Afrilianto, M. (2012). Peningkatan Pemahaman Konsep dan Kompetensi Strategis Matematis Siswa SMP dengan Pendekatan Metaphorical Thinking. Infinity Journal, 1(2), 192-202.

Andayani, F., \& Lathifah, A. N. (2019). ANALISIS KEMAMPUAN PEMECAHAN MASALAH SISWA SMP DALAM MENYELESAIKAN SOAL PADA MATERI ARITMATIKA SOSIAL. Jurnal Cendekia: Jurnal Pendidikan Matematika, 3(1)(1-10).

Fajriyah, L., Nugraha, Y., Akbar, P., \& Bernard, M. (2018). PENGARUH KEMANDIRIAN BELAJAR SISWA SMP TERHADAP KEMAMPUAN PENALARAN MATEMATIS. Journal on Education, 1(2), 288-296.

Harahap, T. H. (2015). Penerapan Contextual Teaching and Learning untuk Meningkatkan 
Kemampuan Koneksi dan Representasi Matematika Siswa Kelas VII-2 SMP Nurhasanah Medan Tahun Pelajaran 2012/2013. Jurnal EduTech, 1(1), 1-19.

Rosyana, T., \& Sari, I. P. (2016). Penerapan Aktivitas Quick On The Draw Melalui Pendekatan

Thinking Aloud Pair Problem Solving Untuk Meningkatkan Kemampuan Komunikasi dan Penalaran Matematis Siswa MA. P2M STKIP Siliwangi. P2M STKIP Siliwangi, 2(2), 192-202.

Sugandi, A. . (2013). Pengaruh Pembelajaran Berbasis Masalah dengan Setting Kooperatif Jigsaw terhadap Kemandirian Belajar Siswa SMA. Jurnal Ilmiah Program Studi Matematika STKIP Siliwangi Bandung, 2, 2.

Suherman, E. (2008). Model belajar dan pembelajaran berorientasi kompetensi siswa. Educare, 5(2).

Sumarmo, U. (2015). Kumpulan Makalah dan Disposisi Matematik serta Pembelajarannya. (Bandung: FPMIPA UPI).

Ulya, I. F., \& Irawati, R. (2016). Peningkatan Kemampuan Koneksi Matematis Dan Motivasi Belajar Siswa Menggunakan Pendekatan Kontekstual. Jurnal Pena Ilmiah, 1(1), 121-130.

Zulfah, Z. (2017). Pengaruh Penerapan Model Pembelajaran Kooperatif Tipe Think Pair Share Dengan Pendekatan Heuristik Terhadap Kemampuan Pemecahan Masalah Matematis Siswa Mts Negeri Naumbai Kecamatan Kampar. Jurnal Cendekia: Jurnal Pendidikan Matematika, 1(2), 112.

Zulfah, Z. (2018). Analisis Kemampuan Peserta Didik SMP di Bangkinang melalui Penyelesaian Soal Pisa 2015. Journal on Education, 1(1), 1-13. 